\title{
"Petishism", or Animals in the City and on the Islands: Case Study of the Island of Silba
}

\section{— Suzana Marjanić, Rosana Ratkovčić}

The first part of this paper (by Suzana Marjanić) documents the fact that city authorities throughout Croatia do not encourage needed care for stray dogs and cats, specifically the construction of state and private shelters for abandoned and lost animals, as well as feeding stations. Zagreb, the capital of Croatia, does not have a shelter for cats. Also documented are exhibitions of animal studies in Croatia, two of which were organised in Zagreb in the same year: an artistic one All Our Animals - Animals as Subjects in Croatian Modern Fine Arts (Modern Gallery, Zagreb, 2017), and another from the aspect of ethnozoology and anthropology of animals - Of Animals and Humans (Ethnographic Museum, Zagreb, 2017), both of which also featured cats.

The second part of the article (by Rosana Ratkovčić) notes the fact that the number of stray cats on Croatian islands increases each year, as pets brought by tourists are frequently left behind at the end of summer vacation. On the example of the island of Silba and its only (eponymous) town, how the local population has self-organised the protection of the island's stray cats is presented.

KEYWORDS: petishism, animal studies, stray cats, island of Silba

\section{THE URBAN JUNGLE: ANIMALS FOR SLAUGHTERING, ANIMALS FOR} PETTING

The beginning of the third millennium is marked by two extremes: we are witnessing revolutionary changes in the understanding of animal rights while horrendous massacres of animals occur (as was also evident at the session organised by Marjetka Golež Kaučič). ${ }^{1}$ In his book Animal and Man: A Contribution to Cultural Zoology (1996), Croatia's first zoo-ethicist Nikola Visković noted the emergence of a disturbing socio-biological process: the global number of species and individuals of so-called wild animals has been

\footnotetext{
1 This article has been presented in 2017 at SIEF (International Society for Ethnology and Folklore) in Göttingen, within the panel discussion "Dwelling of Others: Non-Human Homes from a Puddle to an Animal Reserve" organised by Marjetka Golež Kaučič. The first part of the article has been fully supported by the Croatian Science Foundation under the project Cultural Animal Studies: Interdisciplinary Perspectives and Traditional Practices (IP-2019-04-5621).
} 
reduced $^{2}$ at the same rate as the number of domestic animals, particularly of pet animals ("petishism" or the cult of pets, or nonhuman companions and nonhuman friends as termed by the theoreticians who negate linguistic speciesism) ${ }^{3}$ has increased. Today, when an animal is reduced to a mere object of exploitation, in the process called "a latter-day holocaust" by animal rights activists, it is astonishing that its symbolic value has not disappeared as well. ${ }^{4}$ Alongside Lévi-Strauss' studies of animals as flexible symbols, one should note the work of anthropologists Evans-Pritchard, Edmund Leach, and Mary Douglas. ${ }^{5}$ Of course, when speaking of the beginning of animal studies in anthropology, one needs to note the American anthropologist Lewis Henry Morgan and his book The American Beaver and His Works (1868), wherein he compares the beavers' building of habitats, dams and canals with methods used by human engineers, and along the same line (as noted by S. Eben Kirksey and Stefan Helmreich) opens up the question of animal rights, pointing out that we treat such animals with unmerciful cruelty. ${ }^{6}$ Studies in anthrozoology should certainly include the work of Gregory Bateson, who discussed communication between humans and dolphins; his theory of play, fantasy and mental processes annulled the essentialist differences between human and nonhuman mentality.

Contemporary animal studies have examined numerous aspects of the correlation between animals and humans in urban surroundings. Anthropologist Annabelle Sabloff (2001) wrote that of all human-animal relations, the keeping of animals as companions or pets is one of the most intriguing. In her book Reordering the Natural World, Sabloff argues that contemporary capitalist society augments the conviction that we (urban citizens) are alienated from the rest of nature. At the same time, urban citizens (the research was conducted on a sample of Canadian citizens) relate to the natural world.

I also use this opportunity to note the exceptional book The Horse in the City: Living Machines in the Nineteenth Century (2007) written by Clay McShane, Joel Tarr, and Harriet Ritvo. The book identifies the $19^{\text {th }}$ century as the golden age of the horse. In urban America, the horse, as the most important urban animal, provided the power for not only vehicles that moved freight, transported passengers, and fought fires, but also for equipment in breweries, mills, foundries, and machine shops. In relation to this, I would like to note an entry from Miroslav Krleža's journal Davni dani (Olden Days) written in the period of the First World War, in which he wrote down distressing observations about Zagreb's horses. Specifically, in his olden-day-journal entries, Krleža often records the deaths of innocent animals. For instance, he perceives (and commemorates in writing) the death of a mare that "croaked in Zrinjevac Park [...] While looking on the voiceless death of the equine, a passer-by is peeling and nibbling on roasted chestnuts." Theatre, television, and film actress Eliza Gerner, a friend of Krleža's, spoke of him as

\footnotetext{
Visković 1996: 385

Alongside the term companion, Joan Dunayer (2004) also uses the term pet, albeit not defined speciesistically.

Visković 1996: 16

Arluke, Sanders 1996: 3

Kirksey and Helmreich 2010: 549

Krleža 1977a: 299
} 
being heavily affected by horses clashing on the street: "He literally suffered because of it, and such clashes were a daily occurrence at the time." fates of horses associates Krleža's psycho/biography with Nietzsche's, who collapsed on the streets of Torino in 1888 due to the fate of a pulling horse that was mercilessly beaten by its owner - he put his arms around its neck and sought to protect it, he burst into tears and his soul sunk into despair. ${ }^{9}$ Krleža notes how August Cesarec (author, translator, publicist and political activist, one of the pioneers of the Communist movement in Croatia prior to the First World War) "in an intense ecstasy of joy, rapture, sentimental devotion and even tears [...] has been petting horses on the streets ever since childhood." 10 With the apophthegm "horses and women are equally passive historical phaenomena; both assist in battles," 11 he notes the historical subjugation of women and animals (horses as the central animals in war) in androcentric wars. Shortly after the observed death of the mare, which croaked (I point out Krleža's linguistic speciesism in the context of the animal's fate mentioned above) in Zrinjevac Park, Krleža records the fate of an ox on his way to the slaughterhouse: "[...] amid Ilica Street, a silvery-satin ox is trudging to the abattoir." 12

Furthermore, he notices a run-over dog in a puddle of blood on the tram tracks: "A carnivore feels compassion towards the canine's blood-soaked carcass since it is not 'appetising', since it cannot be eaten as, say, an equally repulsive slain piglet." ${ }^{\prime 13}$ Under date of 20 September 1919, at 11 p.m., he records the memory of visiting a slaughterhouse with Franjo Ciraki: "Premiere night. This is the first abattoir I have visited in my entire life. Sheep eyes in blood. Blood-soaked sheep." 14

Today, as regards horses, they are kept in urban surroundings only as pets for sports entertainment at hippodromes, or as zoo-therapists. The results of a study published in the journal Human-Animal Interaction Bulletin have therefore shown that cortisol levels - in the afternoon and in the morning upon waking up - of a group of adolescents included

\footnotetext{
8 Gerner 1993: 8

9 Wirth 2001: 110

${ }^{10}$ Krleža 1977a: 25

11 Krleža 1977: 350
}

12 Krleža 1977a: 300. In an entry in Olden Days, on 11 May 1917 at 5 p.m., near the Chapel of St. Vitus on Sokolovac in Požega, Krleža records that he is sitting among cockchafers, bumblebees, ants, bees, flies, and May flowers "under chestnut trees in full, exquisite bloom, with [his] palms covered in pollen and (white) petals from daisies and marguerites; the clouded heavenly titans of May are softly drifting above us on the fiddle of the spring wind, in the evening's orange glow. A solemn atmosphere" (Krleža 1977: 253). Ivo Frangeš interprets the aforementioned note as one of Krleža's "warmest Matoš-like visions of Croatian landscape" (Frangeš 1977:309). (I would like to refer to Amiel's saying "any landscape is a condition of the spirit" which, for example, was poeticised in the initial verse "My soul is where enchantment dwells" of the poem At Home by Matoš.) This is followed by a record of a white ox passing by, who left behind him "a comet's tail full of ammonia with a scent of warm manure" (Krleža 1977: 253), and goes on to say that today, this white ox is as ready for the slaughterhouse as we are, "once a God, a subjugator of Europe, and today a four-legged castrated misery" (Krleža 1977: 254). Yet, I would like to add (even though it is irrelevant for the poetic and historical iconogram on anthropoid bestiality) that the aforementioned zoolatric and Greco-mythic analogy refers to a bull (hence, not an ox), in the form of which Zeus ravished Europe.

13 Krleža 1977a: 303

${ }^{14}$ Krleža 1977a: 219, emphasis by S. M. 
in an equine-facilitated programme are significantly lower compared to another group of children who do not interact with horses. ${ }^{15}$

Let us return for a moment to the term pet, which, as I have already stated, animal rights theoretician and feminist Joan Dunayer (2004) does not consider speciesistic; she uses it alongside the term companion. Specifically, the term pet is shunned by many nonhuman rights advocates and denotes an animal that is kept for amusement and companionship.

Historian Keith Thomas considers pets to be domesticated animals with three functions: firstly, they live with humans in their homes (they are let into the house); secondly, they are named (they have an individual personal name); and thirdly, they are not eaten. ${ }^{16}$ Let us observe for a moment the first definition, which says that a companion or pet is an animal living with humans in their homes. Then how do we name animals that live on a chain, attached to a metal leash in the yards of human homes, often on concrete in their own excrement which, unfortunately, is still the case in many households in Croatia, especially in the suburbs (e.g., in the Dubrava district, dogs are often kept on chains in yards, sometimes without doghouses, and sleep on concrete)? I would like to mention the example of a dog in my street with the same fate; truth be told, it does have a doghouse in the yard, but permanently resides in a constricted space. Its "owners" never take it for walks and feed it primarily with scraps from their table. This dog is not kept for amusement (which is the meaning of the term pet) and companionship (which is the meaning of the term animal companion); it is mistreated as a means for keeping trespassers away from the house.

In the following part of the text, the emphasis is placed on abandoned cats - which do not have a home and were once named, but their names have been forgotten. The fact is that cats are generally left to survive on their own, hunting mice and rats, "[ $[.$. The large number of dogs, and especially cats that are fending for themselves outdoors and filling animal shelters [...]." ${ }^{17}$ Specifically, motivated by the idea of cultural animal studies, Croatia's first zoo-ethicist Nikola Visković, Rosana Ratkovčić and I have initiated the publishing of Mačkozbornik ("Catnicle"/"Catmanac", currently in print) with a felinological sequence from the anthropo-zoomorphic cat-headed goddess Bastet ${ }^{18}$ and the anthropomorphic neotenic Hello Kitty to the mythic superhero, the anthropo-zoomorphic Catwoman. While Katharine M. Rogers (2001) chose Garfield for the subtitle of her book The Cat and the Human Imagination: Feline Images from Bast to Garfield, we opted for Catwoman so as to keep the feminine narrative within the felinological fate related to all the Others who are marked as degraded and damaged. Therefore, I will also present certain instances related to the titular subject with selected examples from the collection mentioned above of papers.

As an example, I note the Old Cat Shelter (Stari maček) owned by Ljiljana Horvat Komerički, who sought to provide a safe and comfortable home for cats that had never had

\footnotetext{
15 Pendry, Smith, Roeter 2014

16 Thomas 1983: 112-115

17 Johnson 2009: 74

${ }^{18}$ From whose alternative name Pasht the ambiguous English word pussy is also derived (Sax 2001: 58, 60).
} 
one or were abandoned by their human families. Most of them are found on the streets, sick and injured. The initiative has been supported by many organisations, as well as private persons. Today, Old Cat Shelter is home to 129 cats and is the only shelter in Croatia exclusively for abandoned cats (I would like to mention here that Zagreb, the capital of Croatia, does not have a cat shelter). It is located in the village of Voloder near Kutina, approximately $55 \mathrm{~km}$ from Zagreb. It was built on the estate of the Komerički family in Moslavačka Gora Regional Park and is surrounded by vineyards and the forest. The costs of food, water, heating, medical treatment and hired hands exceed $€ 2500$ per month. The shelter does not receive any support from the government or local authorities. It is almost entirely financed by Josip and Ljiljana Komerički. Hired labour, which is needed from time to time, is financed by Zlata Kilchenmann. They occasionally receive food donations from some Croatian food companies. However, such donations are sporadic, and the shelter cannot depend on them entirely. Veterinary services and medications must be paid in cash. ${ }^{19}$

Furthermore, I quote a story from a Croatian island as conveyed by anthropologist Karmen Turčinov:

Two young men, fishermen Stipe and Ive spent a winter on an island alone, with twenty feral cats. There were many cold and windy days in a row, and the food became scarce. There was only a sufficient quantity of flour and sauerkraut as these goods are not perishable. The young men would prepare a large pot of sauerkraut with bread and give that to the cats. The cats were called "Nikadnerecinemogu" (Never-Say-I-Cannot). But these supplies also became scarce and were slowly running out. Out of fear and discomfort, they no longer opened the front door as the cats were jumping on it at every little sound. The cats were wailing and howling around the house throughout the night, and the storm was very strong. After a few days and nights, the fishermen's lives became unbearable.

One morning, having once again spent the night hungry and sleepless, the fishermen made a decision: they would capture the cats and put them in jute bags. They caught almost twenty. Some of the cats fled, probably realising the goal of this hellish plan. It was an act bordering on insanity - a fight for life or death. The bags were loaded on a ship and transported to a nearby islet situated just shy of a mile from the island. They untied the bags and released the cats on the desolate islet. The distraught cats dispersed around, and the fishermen sailed back to their bay. After this, they did not feel like doing anything. They just wanted peace, peace and more peace.

However, early in the evening, they could not believe their eyes when they saw all of the cats from the islet swimming back in the direction of their bay." ${ }^{20}$

\footnotetext{
${ }^{19}$ Horvat Komerički in Mačkozbornik.

${ }^{20}$ Upon exploring the island, they realised there was no food and estimated that they will only survive if they return to the same port. The cats came back exhausted, wet and hungry, and there was still no food there (Turčinov, Mačkozbornik, manuscript).
} 
As another example, I would like to mention Željka Bišćan who has experience in the coexistence of different animal species (dogs, cats, pigs, sheep, goats, horses, parrots, chickens, ducks, turtles, geckos, fish, hamsters, mice, guinea pigs). In 2017, her house was home to nine dogs, seven pigs, a duck, a rooster and two humans (herself and her husband), which is an extraordinary example of helping animals.

Briefly put, all of these examples serve to demonstrate that it is possible today to help animals which do not live in their natural habitats, but by keeping them as domestic pets or companions in an imposed life on the border between nature and culture, only to be abandoned in worst-case scenarios. ${ }^{21}$

As yet another example, I would like to mention a lady from the suburbs of Zagreb the already-mentioned district of Dubrava - who, during the extremely harsh winter of 2016, made a small improvised shelter for cats out of cardboard boxes to keep their food dry from the snow. I would also like to briefly note Sonja Manojlović, librarian at the National and University Library in Zagreb, who is well-known for her work of rescuing cats. Furthermore, thanks to journalist and activist Vesna Kesić, Prvić Luka has become known as the island of happy cats. We should also mention Mr Jura and Mrs Dragica, who for years have been taking care of two cats, White (10) and Grey (5), which live in a tree hollow in Bundek Park in Zagreb. ${ }^{22}$ In Dubrovnik, a small group of people have created improvised feeding stations at certain locations in the city. As Dubrovnik is a tourist destination with a typically Mediterranean architecture of narrow streets and passages, seventy-five-year-old Mrs Lili Kera provided a street money box to collect contributions for the cats, with requests written in English to raise the tourists' awareness of this local issue. Mrs Kera's pension is around $€ 200$, half of which is spent on stray cats; she also has cat houses in her garden. There are also numerous NGOs in Croatia such as SOS CAT, Prava šapa (True Paw), Prijatelji životinja (Animal Friends), among others.

In contrast, the lives of stray dogs and cats, and hunting them, is a lucrative business in some towns in Croatia. For instance, the City of Split pays 984 kunas for every cat, and 1660 kunas for every dog removed from the streets to a private company from Šibenik and slightly less for carcasses (this linguistic speciesism is used by the newspaper article I quote here), which costs around 1.1 million kunas annually. In 2012, 54 live cats and 839 dead cats were removed, as well as 28 dog carcasses and 224 live dogs. One such collection campaign, carried out recently on Marjan Hill above Split, caused such a stir that the police had to intervene (Vuković 2013).

\section{FELINE EXHIBITIONS}

As I have already stated in the abstract, in this part of the paper, I will note key feline exhibitions in Croatia. As regards the region (i.e., the former Yugoslav countries), the correlation between cats and people has been validated in museums by Piero Pazzi, Venetian art collector

\footnotetext{
${ }^{21}$ Bišćan, Mačkozbornik, manuscript.

${ }^{22}$ Ljudi velikog srca: Deda Jura i teta Dragica brinu o uličnim macama s Bundeka (2016).
} 
and lecturer at the Academy of Fine Arts (Accademia di belle arti di Venezia), who recently founded the Cats Museum in Kotor, Montenegro, where he presented his cat-collection of historical postcards, photographs, publications, illustrations, postage stamps, advertisements and other graphic materials, the oldest of which date to the $17^{\text {th }}$ century, united by the motif of the cat. Thanks to the efforts of the Pazzi, the Maritime and History Museum of the Croatian Littoral joined in the marking of the $100^{\text {th }}$ anniversary of the First World War with the exhibition Miau, miau, što sam ja radila u Prvom svjetskom ratu (Meow Meow, What I Did in the First World War, Rijeka, 2014), which featured around a hundred enlarged historical postcards and photographs from the First World War with the cat as the main character. ${ }^{23}$

Furthermore, I would like to mention here the only cat-monument in Croatia: a wooden sculpture depicting cats, located in Osijek. In Osijek's industrial district, the villa of the Hermann family stands out architecturally and is far better known as the Mačkamama (Cat-Mum) Castle. This is the "feline" moniker of benefactress Paulina Hermann (Nova Gradiška 1859 - Osijek 1939) who, alongside misfortunate humans (vagabonds, impoverished labourers, persons in mental distress), also helped animals, primarily cats. It is believed that caring for animals and helping humans caused her financial ruin at the end of her life. ${ }^{24}$ It would be interesting to gather together the urban myths/legends about Hermann, a.k.a. Cat-Mum, as one of them alleges that she also kept wild cats, even a lion.

The most recent feline exhibition is entitled Mačka u hrvatskoj likovnoj umjetnosti (The Cat in Croatian Fine Arts; exhibition authors: Dajana Vlaisavljević and Snježana Pavičić; curator: Nikolina Šimunović, Head of Prica Gallery; Samobor, 18 October-24 November 2019). Until this exhibition, there were only three key exhibitions in Croatia from the field of fine art animal studies - Sve naše životinje. Animalističke teme u hrvatskoj modernoj likovnoj umjetnosti (All Our Animals - Animals as Subjects in Croatian Modern Fine Arts, Zagreb, Modern Gallery, 9 March-9 May 2017, exhibition author: Dajana Vlaisavljević); the exhibition Srce iznad teka (Heart over Appetite) organised by artist Sanja Burazin (Galić Salon, Split, 1-14 October 2014), organised on the occasion of World Vegetarian Day (1 October) and World Animal Day (4 October) as the first larger-scale domestic exhibition on the subject of animal rights art; and the animal studies exhibition Pas u hrvatskoj likovnoj umjetnosti od 19. st. do danas (The Dog in Croatian Fine Arts from the $19^{\text {th }}$ Century to the Present) Prica Gallery, Samobor, 19 November-15 December 2013 by the same authors who organised the first-mentioned feline exhibition.

The authors commenced the visual journey through fine art animal studies with the animal that is commonly reputed as our best friend; in Slavic languages, however, this animal's name is most commonly used in swearwords, hence the etymological kinship of the words pas (dog) and psovka (swearword). With the feline exhibition, the aforementioned authors have continued their research of animal motifs and subjects within the cycle Animal Studies in Croatian Fine Arts, initiated in 2013 with the already-mentioned canine one.

Briefly put, the exhibition featured artworks by numerous domestic artists created within a period of nearly two decades, from Izidor Kršnjavi’s Pet studija mačjih glava

\footnotetext{
23 Marjanić 2015.

24 "Paulina Hermann".
} 
(Five Studies of Cats' Heads) from 1874 and Studije mačića (Studies of Kittens, from around 1900 - with five white kittens) by Nikola Mašić to, for example, Ivan Kožarić (Mačke / Cats, 1971-2002; Mačka i miš / Cat and Mouse, 1980s; Mačka na cesti / Cat on the Street, 1986), Stipan Tadić (Roadkill, 2015), or Igor Kuduz and his tomcat Mohammad (Revelation Archive - 341 Stories of the Prophet, 2014), which photographically corresponds with the captured yawn of a cat, similar to Kršnjavi who, with his study, also caught the cat's open jaw, either while attacking or while hissing in self-defence. As regards Kuduz's Mohammad, the series had been created from 2014 until 2016, starting from an incidental photograph of Mohammad's yaw, which soon - as the author himself states - turned into systematic, disciplined and somewhat obsessive recording of a oneand-the-same moment in a cat's life. In his own words:

I was captivated by the realisation that I've become reeeeally familiar with my own cat's daily routine, and that I can effortlessly identify the moment at which a yawn could take place. Not one photograph is the result of a long period of pursuing, and I merely recognised the moment. Marko Golub wrote a fantastic text on the whole matter when I organised an ad hoc exhibition at Žitnjak Ateliers, at which I exhibited the entire series, nearly 350 photographs, for the first and hitherto only time.

Alongside the aforementioned first two domestic feline exhibitions (featuring cats as artistic inspiration), I would also like to point out the fact that two more exhibitions on the subject of animals were organised in Zagreb nearly concurrently - an artistic/animal one, and the other from the aspect of ethnozoology and anthropology of animals - the already-mentioned Sve naše životinje. Animalističke teme u hrvatskoj modernoj likovnoj umjetnosti (All Our Animals - Animals as Subjects in Croatian Modern Fine Arts, Modern Gallery, Zagreb, 2017, exhibition author: Dajana Vlaisavljević) and $O$ životinjama i ljudima (Of Animals and Humans, Ethnographic Museum, Zagreb, 22 April-12 November 2017, authors: Željka Petrović Osmak, Tea Rittig Šiško, Gordana Viljetić), both of which, naturally, also featured cats. The ethno-zoo exhibition, therefore, highlighted, among other things, the fact that cats and dogs who once lived in rural homesteads did not have a name, as opposed to, for example, Daisy the cow or Misty the mare. In contrast, today - as pets, within the framework of petishism as matrices of speciesism - they are named, as opposed to all of those nameless animals who are slaughtered daily (Viljetić 2017) - the ones we eat and whose skins we wear, as underscored by Melanie Joy in her book Why We Love Dogs, Eat Pigs, and Wear Cows (2009) on carnism as the ruling dogma.

\section{BERGER’S QUESTION “HOW DO WE SEE ANIMALS?”}

As for the aforementioned animal rights exhibition Heart over Appetite, the fact remains that, concerning urban animals, they are most frequently and continuously present on our plates, in industrial farms and slaughterhouses (which have been removed from 
the scope of both urban and rural surroundings, just like concentration camps), where many of them spend and end their lives. As regards local cases, I would like to note the example of Jerry the Bull, who outwitted his pursuers. Specifically, having escaped from the slaughterhouse, Jerry became the most famous fugitive in Croatia, who was cheered on even by the most adamant meat-eaters. He was given the slogan "We Are All Jerry" (and a Facebook support group "Support for Jerry the Bull") by the press and was ultimately set free, if his owner and slaughterer are to be believed. Jerry escaped from the slaughterhouse depot in Kaštel Stari near Split in 2019, and soon became the most sought-after individual in Croatia. As recorded by writer and journalist Ante Tomić, "the nitwits initially lured the escaped bull with food, and then set up an erotic trap with several young, fairly attractive cows." ${ }^{25}$ What is sad, however, is that Jerry was the star of Facebook and Instagram only for a couple of days, and his fate was soon forgotten as is always the case with all slaughterhouse animals; or, as documented by Ante Tomić:

Our hyperactive world, our attention-deficient civilisation suddenly forgot about Jerry. On Tuesday night, his adventures were still the main subject of news programmes and web portals, and as early as Wednesday nobody mentioned the humorous case of the bull who escaped the butcher's knife. ${ }^{26}$

Truth be told, considering the media structure, this may have only been a media spin that was intended to shift public attention to poor Jerry from a topical political issue that was thereby supposed to have been concealed.

John Berger dedicates part of his essay Why Look at Animals? to imprisoned animals, stressing that, since the $19^{\text {th }}$ century, following the Second Industrial Revolution, animals - in their disappearance from our everyday life - have mostly been adjoined to the family and the society of the spectacle as pets and as prisoners in zoos. This fate also befell the cat on its path to domestication. Therefore, we also applied human hierarchic relationships to the feline world: we speak of cat elites, for example, with the Croatian Association of Felinological Societies, who organise exhibitions of purebred cats and so-called elite races (hence the term "race" has also been assigned to denote the breed), ${ }^{27}$ while on the other hand, domestic cats and other abandoned animals lead "a dog's life" (why not that of a cat, too, within the framework of zoo-comparisons?) as is demonstrated, for example, by the example of Mačkograd (Catville) in Poreč. ${ }^{28}$

Public zoos, which emerged in the $19^{\text {th }}$ century, functioned as an affirmation of colonial power - the conquest of exotic lands. Contemporaneously with this colonial practice of exhibiting exotic animals, the $19^{\text {th }}$ century also saw increased demand for realistic toys of

\footnotetext{
25 Tomić 2019: 26-27.

26 Tomić 2019: 26.

27 Mačkarica, 2016.

${ }^{28}$ On the temporary postponement of the eviction of Mačkograd (2016), http://www.parentium.com/prva. asp?clanak=53193; on Mačkograd moving to a legal shelter (2017), http://porestina.info/mackograd-preselio-u-legalan-azil/; on Poreč opening the first shelter for stray cats in Croatia, https://www.parentium.com/prva. asp? clanak $=61270$
} 
animals. According to Berger's detections, the parallelism of this ideology of the Industrial Revolution in the context of the lives of animals extends even further: realistic toys have prompted a demand for a new toy - a city pet, in which the fate of cats is equally included. Therefore the Japanese Bobtail cat is most famous today as Hello Kitty, a little white cat with a pink bow. She first appeared, according to Wikipedia, on a coin purse in Japan in 1974, and in the US in 1976. Hello Kitty, produced by the company Sanrio and designed by Yuko Shimizu, today denotes hyper-consumerist symbolism based on ethno-tradition. Specifically, in Japan, bobtail cats are believed to bring good luck, prosperity and money. For that reason, porcelain or ceramic cats, the so-called Maneki-Neko (beckoning cats with an upright paw), are produced. Calico cats (Mi-Ke - tricolour) are particularly considered a symbol of good luck. ${ }^{29}$

Hence, today the ideology of pets, as well as realistic toys of animals and Disney's cute anthropomorphic characters seemingly prevent us from facing the gory truth of the contemporary slaughterhouse holocaust, wherein animals have been reduced to raw material as if they were soulless machines.

In the final and most distressing part of his essay, Berger points out the fact that all sites of enforced marginalisation (e.g. ghettos, prisons, mental asylums, concentration camps) have something in common with zoos. However, he thereby adds that viewing the zoo in this sense, that is, merely as a symbol, would be overly easy and overly evasive since zoos, in this modern totalitarianism which we silently witness, merely represent the relations between man and animal; and nothing else (Berger 2007: 255-261).

Hereby, I conclude this part of the text on the cat, the most popular so-called pet today (apparently due to its independence, unlike the dog that requires far more attention, care, and patience) - or companion, to quote Joan Dunayer in her destruction of speciesist determinants - even though cats were the last species to be domesticated - allow me to use a more suitable term - imprisoned. Alternatively, as accurately summarised by French sociologist Marcel Mauss: the cat is the only animal to have succeeded in domesticating man. He was absolutely right. However, here we can also sarcastically add that this animal made a historical journey from sacralisation and demonisation to petishism. Christianity sought to nullify the aforementioned demonisation with the life of St. Gertrude ( $7^{\text {th }} \mathrm{ct}$.), the patron saint of cats, whose feast day is on 17 March. Apart from being the patron saint of cats, she is also the patron saint of travellers, widows, and gardeners, and provides protection from mice and mental illnesses. All of the aforementioned seems to be encompassed by Ivan Večenaj's (Paunchy) Jana with her only companion - a shaggy black cat. ${ }^{30}$

Suzana Marjanić

\footnotetext{
29 According to some interpretations, the Maneki-Neko has a bib under its chin, like the Bodhisattva Jizo.

${ }^{30}$ Ivan Večenaj’s Pupava Jana (Paunchy Jana, 1962), an exceptional surreal-‘naïve’ depiction of Jana with mental suffering who is feeding a black cat milk by a spoon, is included in the aforementioned feline exhibition.
} 


\section{A CASE STUDY OF THE ISLAND OF SILBA}

On Croatian islands, particularly smaller ones, the area's isolation positively influences the self-organisation of the local population alongside the participation of several tourists, who work together on raising funds for food, medical treatment, and spaying and neutering of the island's cats.

The number of stray cats on islands is constantly increasing as pets brought by tourists are left behind at the end of summer vacation. On the example of the island of Silba and its only (eponymous) town, we will recount the positive practice of self-organisation of the local population in protecting and caring for the island's stray cats.

Several islanders have started caring for abandoned cats at their initiative by letting them into their homes and providing them with food, shelter and protection, including Mrs Ankica Vukorepa, and Mrs Ljiljana and Mr Aljo, husband and wife.

The Society for the Protection of Natural and Cultural Heritage of the Island of Silba has recently initiated the so-called "Kitten Department," bringing together islanders and their guests who work together to protect cats. After collecting money for food for abandoned cats, members distribute the food to places at which cats gather, such as the island's landfill. The collected donations also cover cat food for the locals who care for a large number of cats in their homes. Therefore we can say that stray cats on Silba are looked after in terms of food thanks to the efforts of the "Kitten Departmen" and several especially engaged individuals. It has also been noted that feral cats live in the island's forests and eat whatever they can catch.

In 2016, organised by the "Kitten Department" and thanks to special efforts by Petra Hillinger, a large-scale campaign of spaying and neutering of the island's cats was initiated to prevent the increasing number of the island's stray cats. Petra Hillinger, an Austrian tourist who has spent her summers on Silba since childhood, brought her veterinarian friends who voluntarily spayed and neutered around sixty cats at their own expense. Notices inviting the residents to bring in their cats to be spayed/neutered were put up on the island, and traps were set for feral cats. Unfortunately, some cat owners did not want to spay or neuter them even though it was free of charge and prefer to throw new-born kittens into the sea. It should also be noted that, according to experience, systematic neutering within a one-year period reduces the population of cats by up to 40 per cent.

The abandoned cats that gather on the island's landfill are fed by Mrs Ljiljana and her husband Aljo, who also care for a large number of cats in their home. At the time I visited them, they were quite concerned about Bijeli (Whitey), a male named after the colour of his fur, since he started developing skin cancer on one of his ears due to lack of pigment and exposure to the sun. With great effort by Mrs Ljiljana and after taking the cat to a vet in Zadar to be operated on, the cat pulled through, the infected part of the ear was surgically removed, and the cat is healthy today, albeit missing one ear. ${ }^{31}$

\footnotetext{
${ }^{31}$ I heard an anecdote from the residents that a nun living on the island, a "švora", once reproached Aljo for his caring for cats, to which he replied that "if she wears this habit (nun's attire) of hers, she might as well know that animals are God's creatures."
} 
Some locals who are always on the island (i.e. throughout the entire year), such as Mrs Verica and Mrs Đimberta, provide care and food for the cats who live in the homes of people who only spend their summers on the island.

Among the islanders who took on themselves the care and protection of abandoned cats without any previous organisation, we should especially note Mrs Ankica Vukorepa, who gathers cats in her home and has been caring for them for more than fifteen years.

Mrs Ankica comes from Miljevci near Drniš, where she worked as a primary school teacher; having retired, she moved to Silba together with her late husband Čedo, into her family's old house. She cared for cats while she was still living and working in Miljevci; she remembers an anecdote from that time, about a cat who knew which of her students brought good lunch from home, so he would sit next to this student and wait for a treat or two. This cat was later run over by another student with a motorcycle, with the kind of violent malice that is characteristic of children but is little spoken of as they are typically idealised.

Among cats that are cared for by Mrs Ankica today, Krivi (Crooked) is the only cat that came to Silba from Miljevci. He was brought to their home by Ankica's husband Čedo as a kitten; after her husband passed, she found the cat sleeping on his grave. The cat got his name because he had broken his spine and has had a crooked posture ever since.

With typically feline opportunism, in summer months Krivi moves to the home of Mrs Gavrilović, one of the tourists who resides on the island only during summer and cares for the island's cats within that period. There are fewer cats at Mrs Gavrilović's than there are at Mrs Ankica's, so Krivi has chosen the former location as his summer residence, probably due to more food and more care provided. In winter, when Mrs. Gavrilović leaves the island, Krivi returns to Mrs. Ankica's. Mrs. Ankica is extremely saddened by Krivi's summer infidelity since she is especially attached to him due to the memory of her late husband.

When notices were put up on the island, which informed the residents of the spaying/ neutering programme organised by Petra Hillinger, they featured the photograph of Krivi, who thereby became a kind of trademark of Silba's cats, as well as of the care provided for them by these selfless women.

When Petra Hillinger resides on Silba, she also gathers a large number of cats in her home, whom she cares for and feeds. On her fence, she put up many notices advocating the care for cats, a donation box, and also the photograph of Krivi. Petra Hillinger's house on Silba is close to Mrs. Ankica's home, so her cats also drop by Petra's at mealtime.

Mrs. Ankica feeds, fosters and cares for approximately thirty cats in her home; the exact number is unknown as new cats keep coming. The number of cats in her home is this high since people throw abandoned cats or young kittens over her fence; she once found seven in a single day.

Mrs. Ankica calls the cats she cares for Moje blago (My Treasure). While she was talking about them, she was spraying water on some disobedient cats while saying the proverb "Svaka ptica ima svoga orla" (literally "Every bird has its eagle", meaning "There is always someone who is more powerful or influential", "There is a sky above the sky"), which is in contrast to the harmless solution she has for their disobedience. Mrs. Ankica told us that she is wrought with sadness over the suffering of her cats and the pain inflicted upon them by people. 


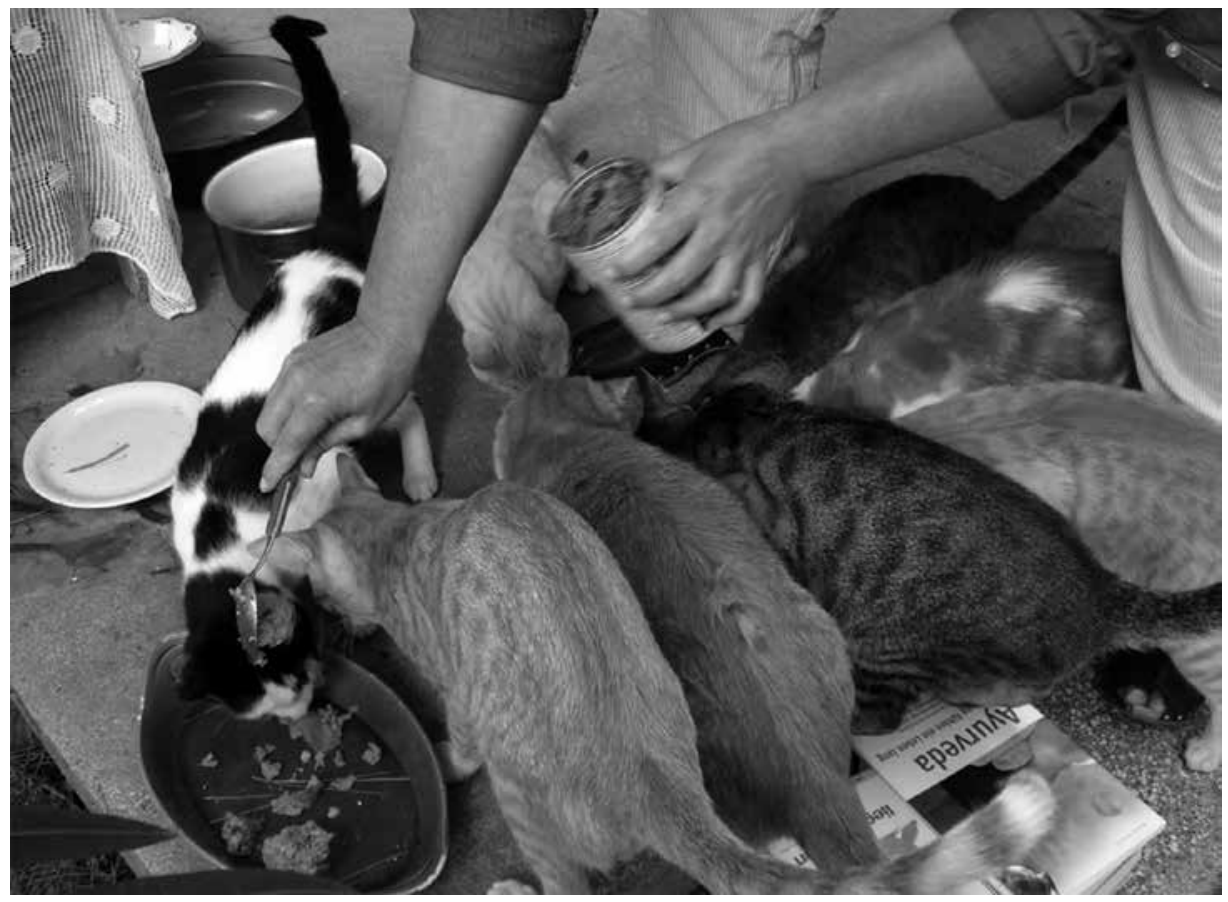

Fig. 1. - Lunch at Petra Hillinger's home, Silba, 2017 (photo by Rosana Ratkovčić).

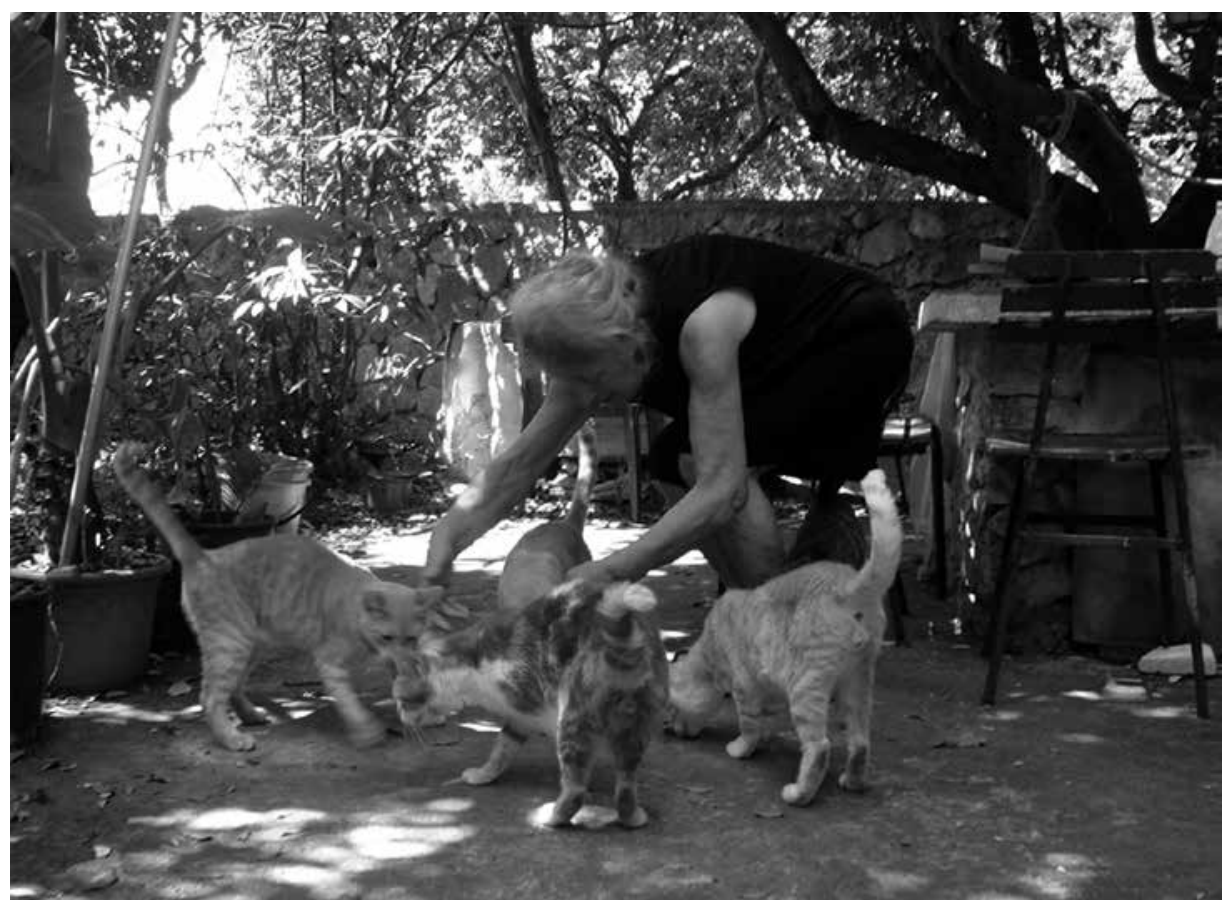

Fig. 2. - Mrs. Ankica Vukorepa and her cats, Silba, 2017 (photo by Rosana Ratkovčić). 
In and around Mrs. Ankica's house, everything is subordinated to cats. The property is full of makeshift cat houses, every cat has its own nook, but they also like dwelling in twos in a single house.

Mrs. Ankica feeds her cats several times a day; she prepares a mixture of bread soaked in soup or milk and store-bought cat food, a bit of dry kibble, some canned food, even though she keeps the latter for cats that are sick and eat very little. When she exits the house, she leaves food for them so that they stay inside; otherwise the cats go after her and follow her around the island. Furthermore, Mrs. Ankica always keeps a pouch of cat food in her bag so that she could feed the cats she meets along the way.

Apart from cats, in her love of animals, Mrs. Ankica also keeps turtles and a crow that she rescued from being attacked by cats. Afterwards, the crow became tame and stayed in Mrs. Ankica's garden.

Alongside Krivi, other cats that live with Mrs. Ankica include Moro (Dusky), Žuti (Amber), Brzi (Speedy), Bila (Snowball), Crni repić (Blacktail). A female named Mica (Kitty) escaped from the ship and returned when they wanted to take her away to Austria. There is also a pair of identical twins with unusual, lavender-coloured fur, and they both have an injured eye. One of the males had a broken jaw, which left him with a string of saliva constantly hanging from his mouth. Moro got his name after the colour of his fur and is one of Mrs. Ankica's favourites; he is skinny and a picky eater. Moro and Bila are the only cats allowed to sleep in the house.

Silba's cats have been immortalised in the works of Marija Ujević Galetović, one of Croatia's most significant female sculptors, who is linked to Silba through family and spends most of the year there. The cat motif is inevitable in her work and one of her trademarks, particularly in her numerous sculptures of hybrid figures of women with cat's heads. On Silba, she opened the Marija Ujević Galetović Gallery, arranged as an outdoor sculpture garden, with her sculptures on display. Marija Ujević Galetović, her sculptures and the cats of Silba are also the subject of the animated film Mačka je uvijek ženska ( $A$ Cat Is Always Female, 2019) by Martina Meštrović and Tanja Vujasinović, with which the authors have honoured their professor through a feminist lens.

Similar initiatives by locals and tourists for the protection of cats on the islands are also present on the island of Prvić in Šibenik archipelago, which saw the implementation of the project entitled Prrrrvić, otok sretnih mačaka i zadovoljnih ljudi (Prrrrvić, Island of Happy Cats and Contented People). According to the 2001 census, the island of Prvić with its two boroughs, Šepurine and Luka, had 453 residents. ${ }^{32}$ The locals realised that there were more cats than people on the island and decided to do something about it. The aim of the project Purrrrvić, Island of Happy Cats and Contented People includes not only systematic neutering of the island's cats, but also the fostering of cats and educating the local community. The initiative also has a Facebook page, Otok sretnih mačaka (The Island of Happy Cats). ${ }^{33}$

\footnotetext{
32 "Mačkarica - sve o mačkama" / "Cat Lady - All About Cats". http://www.mackarica.com/vijesti/prvic-je-postao-otok-sretnih-macaka-i-zadovoljnih-ljudi/ (accessed on 2 March 2017)

33 "Otok sretnih mačaka" / "The Island of Happy Cats". https://www.facebook.com/ Otok-sretnih-mačaka-1574977072730812/?fref=ts (accessed on 2 March 2017)
} 
On the island of Cres, the initiative entitled Cres Cat Rescue was launched by academic painter Koraljka Polaček in 2016, to control the population of the island's cats and provide them with a better life. ${ }^{34}$ As a member of the Animal Protection Society of Mali Lošinj, she implements the trap-neuter-release (TNR) programme, and collaborates with the volunteers in Rijeka and Zagreb and Veterinary Clinic Rijeka - Veterinary Clinic Mali Lošinj. Alongside Koraljka, Diana Primožić from the NGO Vis Vitalis also participates in the neutering programme of Cres's cats, all of which are neutered at Veterinary Clinic Rijeka. ${ }^{35}$ Neutering of the island's cats is primarily financed by the Municipality of Cres, which tends to the wellbeing of its animals. Thus far, 280 cats on Cres have been neutered, many of them received medical treatment, and more than 40 cats have been adopted. Thanks to the volunteers, a meal is provided daily for around one hundred cats at various locations on the island. ${ }^{36}$ Having moved to Cres, Koraljka Polaček began artistically painting fragments of Cres stone, and cats have been the main motif of her painterly expression for quite a while. The charity sale of Koraljka's paintings through online auctions partly covers the costs of food, medicine, and other supplies for cats. ${ }^{37}$

As we can see from the study, in Croatia, city governments do not encourage necessary care for stray dogs and cats, such as the construction of public and private shelters for abandoned and lost animals. However, Croatia's smaller islands as isolated environments serve as an example of self-organisation of the local population who, together with several tourists, jointly work on raising funds, feeding, and spaying and neutering of the island's cats (on the example of the island of Silba).

Rosana Ratkovčić

Translated by Mirta Jurilj

\section{REFERENCES}

Arluke, Arnold and Clinton R. Sanders. 1996. Regarding Animals. Animals, Culture and Society. Philadelphia: Temple University Press.

Berger, John. 2007. Why Look at Animals?. In: The Animals Reader. The Essential Classic and Contemporary Writings. Eds. Linda Kalof and Amy Fitzgerald. Oxford, New York: Berg, pp. 249-261.

Bišćan, Željka. Mačke u mojim i božjim očima [The Cats Through Mine and God's Eyes]. In: Mačkozbornik (Catnicle/Catmanac). Eds. Suzana Marjanić and Rosana Ratkovčić, forthcoming.

Dunayer, Joan. 2009 (2004). Specizam / Speciesism. Zagreb: Dvostruka duga; Institut za etnologiju i folkloristiku / Institute of Ethnology and Folklore Research.

\footnotetext{
34 “CRES CAT Rescue”. https://www.facebook.com/CresCatRescue/ (accessed on 2 December 2019)

35 "Mačkarica - sve o mačkama" / "Cat Lady - All About Cats". http://www.mackarica.com/vijesti/da-je-barem-vise-ovakvih-ljudi-na-svijetu-upoznajte-koraljku-dobru-dusu-koja-brine-o-mackama-na-cresu/ (accessed on 2 March 2017)

36 "CRES CAT Rescue". https://www.facebook.com/CresCatRescue/ (accessed on 2 December 2019)

37 “CRES CAT Rescue”. https://www.facebook.com/CresCatRescue/ (accessed on 2 December 2019)
} 
Frangeš, Ivo. 1977. Krleža i Kranjčević [Krleža and Kranjčević]. Forum 9, pp. 305-344.

Gerner, Eliza. 1993. Oproštaj s Gvozdom: Razgovori s Krležom / Farewell to Gvozd: Talks with Krleža. Zagreb: AGM.

Horvat Komerički, Ljiljana. Mačji dom Stari Maček, Voloder [The Old Cat House in Voloder]. In: Mačkozbornik (Catnicle/Catmanac). Eds. Suzana Marjanić and Rosana Ratkovčić, forthcoming.

Johnson, Jill. 2009. Dogs, Cats and Their People: The Place of the Family Pet and Attitudes about Pet Keeping. A Thesis. Manuscript. Waterloo: University of Waterloo. Available at: https:// pdfs.semanticscholar.org/4e27/a5f04797e25bd4c0c1325b06fc86ebd09cac.pdf (Accessed on 13 November 2019).

Joy, Melanie. 2009. Why We Love Dogs, Eat Pigs, and Wear Cows. San Francisco: Conari Press.

Keith, Thomas. 1983. Man and the Natural World. A History of the Modern Sensibility. New York: Pantheon Books.

Kirksey, S. Eben and Stefan Helmreich. 2010. The Emergence of Multispecies Ethnography. Cultural Anthropology 25/4, pp. 545-576. Available at: https://goo.gl/JWrSbl

Krleža, Miroslav. 1977. Dnevnik 1914-17: Davni dani I / Journal 1914-17: Olden Days I. Sarajevo: NIŠP Oslobođenje.

Krleža, Miroslav. 1977a. Dnevnik 1918-22: Davni dani II / Journal 1918-22: Olden Days II. Sarajevo: NIŠP Oslobođenje.

Ljudi velikog srca: Deda Jura i teta Dragica brinu o uličnim macama s Bundeka [People with a Big Heart: Mr. Jura and Mrs. Dragica Care for the Street Cats of Bundek]. 2016. Available at: http://www.index.hr/ljubimci/clanak/ljudi-velikog-srca-deda-jura-i-teta-dragica-brinu-o-ulicnim-macama-s-bundeka/880783.aspx (Accessed on 5 May 2018).

Mačkarica [Cat Lady]. 2016. "http://www.mackarica.com/vijesti/u-zagreb-dolazi-europska-macja-elita-i-naravno-svi-ste-pozvani/”. (Accessed on 5 March 2017).

Marjanić, Suzana. 2005. Glasovi "Davnih dana”: transgresije svjetova u Krležinim zapisima 1914-1921/22 / Voices of "Olden Days": Transgressions of Worlds in Krleža's Records 1914-1921/22”. Zagreb: Naklada MD.

Marjanić, Suzana and Sanja Burazin. 2014. Dajemo glas onima na svojim tanjurima [We Give Voice to the Ones on Our Plates]. (Sanja Burazin interviewed by Suzana Marjanić). Zarez, No. 394, 23 October 2014. Available at: http://www.zarez.hr/clanci/dajemo-glas-onima-na-svojim-tanjurima (Accessed on 13 November 2017).

McShane, Clay; Joel Tarr and Harriet Ritvo. 2007. The Horse in the City: Living Machines in the Nineteenth Century. Johns Hopkins University Press.

Odbjegli bik osvojio srca građana pa mu napravili grupu podrške: 'Jerry, želim ti sreću! Ak' treba buraz, ja ću ti pomoći' [The Runaway Bull Captures People's Hearts and Gets a Support Group: 'Godspeed, Jerry! If You Need Help, Bro, Here I Am!']. Available at: https://net. $\mathrm{hr} /$ danas/hrvatska/odbjegli-bik-osvojio-srca-gradana-pa-mu-napravili-grupu-podrskejerry-zelim-ti-srecu-ak-treba-buraz-ja-cu-ti-pomoci/ (Accessed on 13 November 2019).

Paulina Hermann. (http://essekeri.hr/bio/67-paulina-hermann). (Accessed on 5 March 2017).

Pendry, Patricia; Annelise N. Smith and Stephanie M. Roeter. 2014. "Randomized Trial Examines Effects of Equine Facilitated Learning on Adolescents' Basal Cortisol Levels". Human-Animal Interaction Bulletin vol. 2, no. 1, pp. 80-95. Available at: https://wsuwp-uploads. s3.amazonaws.com/uploads/sites/609/2014/04/effects-of-equine-facilitated-learning.pdf (Accessed on 1 September 2019).

Rogers, Katharine M. 2001. The Cat and the Human Imagination: Feline Images from Bast to Garfield. Ann Arbor: University of Michigan Press. 
Sabloff, Annabelle. 2001. Reordering the Natural World: Humans and Animals in the City. Toronto: University of Toronto Press, Scholarly Publishing Division.

Sax, Boria. 2001. The Mythical Zoo. An Encyclopedia of Animals in World Myth, Legend, \& Literature. Santa Barbara, Denver, Oxford, England: ABC - CLIO.

Tomić, Ante. 2019. San odmetnika Jerryja. Priča o mladom biku koji je pobjegao iz klaonice [Jerry the Rebel's Dream. The Story of a Young Bull Who Escaped from a Slaughterhouse]. Jutarnji list, 2 November 2019, pp. 26-27.

Turčinov, Karmen. "Mačka zvana Nikadnerecinemogu" / "The Cat Called Never-Say-I-Cannot". In: Mačkozbornik (Catnicle/Catmanac). Eds. Suzana Marjanić and Rosana Ratkovčić, forthcoming.

Viljetić, Gordana. 2017. Okokućad, gospodari srca i domova ili robovi ljubavi - kućni ljubimci $\mathrm{u}$ teoriji [Animals Around the House, Masters of the Heart and the House, or Slaves to Love - House Pets in Theory, Space and Time]. In: O životinjama i ljudima / Of Animals and Humans. Ed. Željka Petrović Osmak. Zagreb: Ethnographic Museum, pp. 90-126.

Visković, Nikola. 1996. Životinja i čovjek. Prilog kulturnoj zoologiji / Animal and Man. Contribution to Cultural Zoology. Split: Književni krug.

Vuković, Vinko. 2013. Bitka za splitski posao stoljeća: svaka uklonjena mačka košta 964 kn, a pas čak 1660 kn! [Fighting for the Deal of the Century in Split: 964 Kunas for Each Removed Cat, and an Incredible 1660 Kunas for a Dog!]. Available at: http://www.slobodnadalmacija. $\mathrm{hr} /$ novosti/hrvatska/clanak/id/213487/bitka-za-splitski-posao-stoljeca-svaka-uklonjenamacka-kosta-964-kn-a-pas-cak-1660-kn (Accessed on 15 March 2019).

Wirth, Jason M. 2001. “Animal Desiring: Nietzsche, Bataille, and a World Without Image”. Research in Phenomenology 31, pp. 96-112. 


\section{PETIŠIZAM ILI ŽIVOTINJE U GRADU I NA OTOCIMA: SLUČAJ SILBE Suzana Marjanić, Rosana RatkovČić \\ $\infty$}

Prvi dio članka (Suzana Marjanić) dokumentira kako gradske vlasti u Hrvatskoj ne potiču potrebnu skrb za pse i mačke lutalice - gradnju državnih i privatnih skloništa (azila) za napuštene i izgubljene životinje, kao ni hranilišta. Zagreb kao glavni grad Hrvatske nema azil za mačke. Završni dio toga prvoga dijela članka dokumentira ključne animalističke izložbe u Hrvatskoj. Tako su iste godine organizirane dvije animalističke izložbe u Zagrebu - jedna likovnoanimalistička, a druga iz aspekta etnozoologije i antropologije životinja - Sve naše životinje. Animalističke teme u hrvatskoj modernoj likovnoj umjetnosti (Moderna galerija, Zagreb, 2017, autorica izložbe: Dajana Vlaisavljević) i $O$ životinjama i ljudima (Etnografski muzej, Zagreb, 2017., autorice: Željka Petrović Osmak, Tea Rittig Šiško, Gordana Viljetić), na kojima su svoje izložbeno mjesto pronašle, naravno, i mačke.

Drugi dio teksta (Rosana Ratkovčić) upozorava kako se na hrvatskim otocima povećava broj mačaka lutalica zbog kućnih ljubimaca koje dovode turisti te ih nakon završetka ljetovanja ostave na otoku. Na primjeru otoka Silbe i jedinog istoimenog naselja na otoku, autorica demonstrira pozitivnu praksu samoorganiziranja lokalnog stanovništva u brizi i zaštiti otočkih mačaka lutalica. Postoji nekoliko otočana koji su se isprva samoinicijativno počeli brinuti o napuštenim mačkama, okupljajući ih u svojim domovima i pružajući im hranu, zaštitu i njegu. Nedavno je pri Udruzi za zaštitu prirodne i kulturne baštine otoka Silbe osnovana sekcija „Mačićc“ koja okuplja otočane i njihove goste koji zajedno rade na zaštiti mačaka. Prikuplja se novac za hranu za napuštene mačke koju članovi sekcije raznose na mjesta na kojima se mačke okupljaju. Zalaganjem Petre Hillinger, turistice iz Austrije, organizirana je velika akcija steriliziranja i kastriranja otočkih mačaka kako bi se zaustavilo povećavanje broja mačaka lutalica na otoku.

Suzana Marjanić, Ph.D., Research Advisor, Institute of Ethnology and Folklore Research, Šubićeva 42, Zagreb, suzana@ief.hr

Rosana Ratkovčić, Ph.D., Assistant Professor, University North, Trg Žarka Dolinara 1, Koprivnica, Croatia, rosana.ratkovcic@zg.t-com.hr 